\title{
CONSERVATION FOR THE LONG-HAUL: PROTECTING CULTURAL AND NATURAL RESOURCES THROUGH FINANCIAL, LEGAL, AND PROGRAMMATIC STRATEGIES
}

\author{
JULIA MURPHY, JEREMIAH LEIBOWITZ \& ANNA HUDSON \\ Cibolo Nature Center \& Farm, Texas A\&M Institute of Renewable Natural Resources, USA
}

\begin{abstract}
Historic Herff Farm in Boerne, Texas is an iconic Texas Hill Country landscape that has been carefully restored by the Cibolo Nature Center and Farm and is now being transformed into a center for sustainable living. In 2016, the farm was recognized with a Preservation Texas Honor Award, and the homestead is listed on the National Register of Historic Places. A new Texas Historical Commission marker celebrates the life of the farm's namesake, Dr. Ferdinand Ludwig von Herff, a prominent San Antonio physician who emigrated from Germany in the mid-1800s. Taking cues from its past, Herff Farm is a destination that currently hosts a weekly farmers market, "Farm Classroom" for schoolchildren in the area, with demonstrations showcasing best practices for water conservation, renewable energy and small-scale agricultural production. This paper highlights financial, legal and programmatic strategies that have been utilized to conserve the property in perpetuity. The Texas Historic Preservation Tax Credit was established by the Texas Legislature in 2015 for certified rehabilitation work on historically-designated properties and equals $25 \%$ of eligible costs and expenses. This is a valuable financial tool for owners and investors who wish to rehabilitate cultural treasures to the Standards of Rehabilitation of the Secretary of the Interior. The property has also been placed under a voluntary conservation easement, a legal agreement between the landowner and a land trust that limits the owner's development rights in order to maintain its natural and cultural features. Finally, building public support by providing access, services and programs helps ensure a culture of stewardship and sense of ownership by the greater community. These strategies could be employed by conservation-minded landowners with limited resources who seek to preserve cultural and natural resources.
\end{abstract}

Keywords: conservation, historic, preservation, Texas, German, vernacular, easement, tax, rehabilitation, farm.

\section{INTRODUCTION}

The Herff Farm is owned and operated by the non-profit Cibolo Nature Center \& Farm, also the parent organization of the adjacent 100 -acre, regionally treasured Cibolo Nature Center, founded in 1988. The farm is a classic Texas Hill Country landscape comprised of 60 acres bordering Cibolo Creek with an original farmhouse and outbuildings, and pastures and fields once used for livestock and fruit tree production. Acquired by the non-profit in 2007, the original cut limestone home was carefully restored over the next seven years to the exacting standards of the National Registry of Historic Places. As a result, the organization was one of the first non-profits to benefit from the Texas Historic Preservation Tax Credit and was able to recoup a portion of the rehabilitation costs in 2016. Also in 2016, the loan on the property was paid off in full. As an added layer of protection, the Cibolo Nature Center and Farm (CNC\&F) board of directors elected to place the homestead and grounds under a voluntary permanent conservation easement, held by the Texas Agricultural Land Trust. A conservation easement is the legal adhesive that binds a property owner's stewardship goals to the land. Donors of conservation easements relinquish their development rights but retain title and some other rights to their property. 
Though some mission-centered improvements will be allowed under the terms of the agreement, essentially Herff Farm will remain as it looks and functions today: a beautiful and bucolic reminder of the local heritage and a demonstration center for sustainable living in the modern world.

\section{CONSERVATION VALUES}

With a mission of conservation of natural resources through education and stewardship, the CNC\&F hosts tens of thousands of visitors each year who come to learn about and experience the natural world firsthand. The nature center's initiatives are impactful and relevant to today's issues, as precious green space for personal replenishment and passive recreation, working lands that generate local agricultural products, and habitat for threatened plant and animal species are increasingly under siege for competing uses. As the board of directors was working to acquire Herff Farm, a project that began in 1999, the population of Boerne exploded, increasing by $87 \%$ between 1997 and 2014 . This in turn increased demand on local water supplies and led to more land fragmentation. According to Texas A\&M Institute of Renewable Natural Resources, between 1997 and 2012, Kendall County experienced a $105 \%$ increase in the number of parcels less than 100 acres and a $15 \%$ decrease in acreage of crop and grazing land [1]. Indeed, the entire Texas Hill Country is threatened by land fragmentation and more intense development, leading to increased storm water runoff, diminished recharge to our drinking water sources, and a myriad of other issues related to sprawl. Thus, in order to protect water quality and quantity; a destination for experiential learning in nature; and a historically important property that illustrates the agrarian roots of the community, permanent protection was sought through a conservation easement. On the Deed of Conservation Easement for Herff Farm, the Conservation Values are listed as: " 1 . The Property provides valuable open space including ranchland, rangeland, farmland and native wildlife habitat; 2 . The Property provides areas of significant natural and ecological value; 3. The Property provides significant public benefits to the citizens of Kendall County and the state of Texas, and to visitors to the area [2]." The importance of these values and the services that the CNC\&F provide to the community are explored more fully below.

\subsection{Water quality and quantity}

The protection of Herff Farm impacts water quantity and quality for the region. Cibolo Creek, which runs along the northeastern side of the property, provides critical recharge to the Edwards and Trinity aquifers, the primary source of drinking water for the Greater San Antonio area. Visible signs of how we have collected and stored water for household and agricultural use stand on the property, including the original hand-dug well and restored windmill and cypress tank. Further, visitors can observe how their forebears collected water from the metal roof of the homestead and stored it in a 1200 gallons underground cistern. Now, modern rainwater catchment systems and tanks have been installed and assist CNC\&F's teachings about drought-tolerance in south central Texas while nurturing landscaping, backyard gardening and successful agricultural production. The land will also feature low-impact development tools, such as rain gardens, that slow and cleanse polluted storm water before it rejoins the streams and creeks that feed into the aquifers.

\subsection{Research and education}

Twenty acres of prairie are being restored with native grasses and wildflowers that provide critical food sources for migrating pollinators, such as the Monarch butterfly, and their 


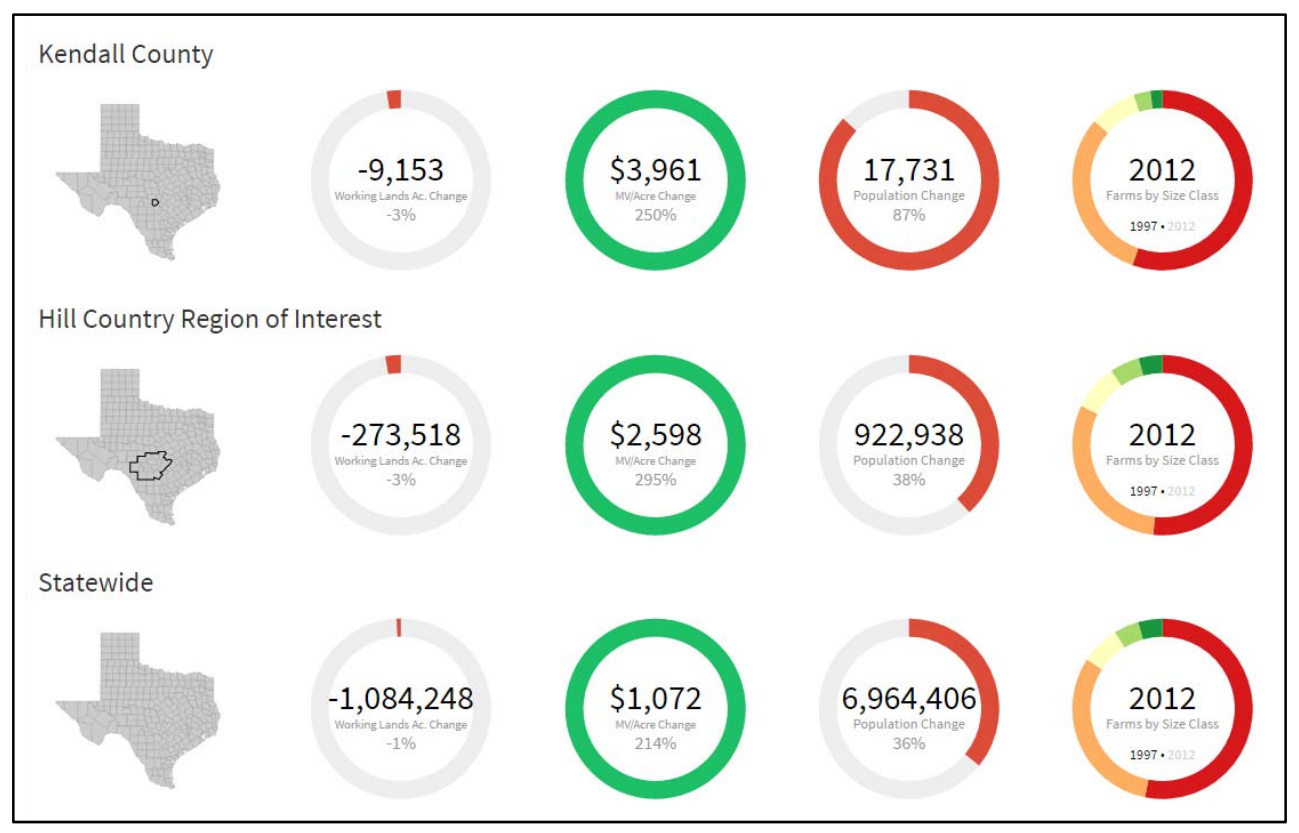

Figure 1: Comparison of land use, market value, population and ownership size. (C 2017 Texas A\&M IRNR. All rights reserved.)

larvae. As the state insect of Texas, the Monarch and has become a symbolic threatened species, negatively impacted by loss of habitat along their North American flyway, from Mexico to Canada. Their twice-annual migrations take them through the Texas Hill Country, and since 2002, the CNC\&F has collected Monarch activity data that it shares with the Monarch Larva Monitoring Project at the University of Minnesota. In addition to eradicating invasive species and returning sustainable native plant life to the prairie, the project will be used to teach others best practices on their own land in support of biodiversity with regional importance.

CNC\&F's primary mission is developing programs and opportunities for people of all ages to engage in lifelong learning and a sense of ownership in our future environmental health. Each school year, thousands of kids participate in CNC\&F's award-winning "Outdoor Classroom," where they get their "hands in the dirt," while at the same time acquiring Texas Essential Knowledge and Skills (TEKS) in science and social studies. "Farm Classroom," has extended this learning to Herff Farm where programming addresses organic fruit and vegetable production, backyard chickens, beekeeping, and other permaculture and homesteading techniques. A newly constructed Garden Barn and one-acre Teaching Garden provide a subject-appropriate venue for teaching how mankind affects the land and how it affects mankind, sustainable living techniques and management of natural resources. Launched in 2016, Nature School provides an early introduction to these concepts to the preschool set, and plans are in place to construct an enhanced campus with state-of-the-art facilities that promote experiential learning. Acknowledging that education is a life-long pursuit, $\mathrm{CNC \& F}$ offers adults a rich selection of opportunities to become citizen scientists, attend workshops, and participate in the care and stewardship of natural assets. 


\subsection{Preservation of local heritage}

As a witness to the settlement of the area around Boerne, the farm has stood through battles, droughts, and decline. The farm's namesake, Dr. Ferdinand Herff, was a prominent physician who built the homestead for a country retreat in the $1850 \mathrm{~s}$. After performing cataract surgery that restored the failing eyesight of a Lipan Apache chief, Dr. Herff and his family were spared the attacks by Native Americans that others endured. Over time, he amassed thousands of acres, then partitioned and passed along much of the land to his heirs. In the 1930s, the farm and homestead were acquired by the Rozelle family who ran a successful apple and fruit orchard. The historic drought of 1957 eventually led to its demise. The farm land is an authentic representative of history, its stories reflecting experiences familiar to many, while the Cibolo Creek has provided life and sustenance throughout the generations. In 2009, the Herff-Rozelle Farm was accepted into the National Register of Historic Places, meeting local levels of significance for Agriculture, Person, and Architecture as "an intact complex of residential and utilitarian structures that exemplify rural life in nineteenth and twentieth century Texas [3]." This designation is a requirement for utilizing federal and state historic tax credits to offset rehabilitation expenses, explained below.

\section{CONSERVATION EASEMENTS}

To prevent the property from conversion to other land uses, the non-profit CNC\&F, not subject to income or franchise taxes, elected to place the acreage in a conservation easement, incurring the costs to do so even with no tax offset that is available to traditional private landowners. There are many definitions for a conservation easement, but in general a conservation easement is a voluntary, legal agreement between a landowner and a land trust for the purpose of holding the development rights in trust in order to protect the property's conservation values. Many unfamiliar with this easement instrument wrongly assume that a land trust, or the government, is dictating the terms of the easement. However, the document is completely negotiated voluntarily. One possible exception involves conservation easements wherein a landowner is being paid for the easement (discussed below in more detail). The paying federal or state agency may have certain language that is required, by law, to be incorporated in the easement. Generally, this does not impact the landowner's intent for protecting the land. A conservation easement is also known as a Deed of Conservation Easement. It is a legal document that is filed in the real property records of the county in which the property resides. As such, the easement "runs with the land" meaning that even if the land changes ownership, the easement will remain in place. For comparison, examples of other easements that run with the land include electrical easements, water line easements, sewer easements, right of way easements, and mineral easements. When investigating a property's title history, the title commitment will list any easements of record that encumber the land. Similarly, a conservation easement will be listed on future title commitments.

A conservation easement will address the limitations on, or extinguishment of, the development rights. In general, development rights enable the landowner to build, excavate, subdivide, extract minerals, and develop water resources, for example. Limitations are negotiated based on the needs, desires and long-term goals of the landowner. The overriding objectives of the conservation easement may be to protect the land and water resources, but that does not mean the landowner loses all control of the property. Most importantly, the document outlines the conservation values of the property. The conservation values form the basis for pursuing a conservation easement and are codified in 
the Internal Revenue Service's tax code section 170(h), which outlines the requirement for a qualified conservation contribution.

\subsection{Types of conservation easements}

In general, there are three types of conservation easements: donated, purchased, and bargain sale. These terms refer to how the landowner chooses to dispose of the easement's value. A donated easement means that the landowner burdens her property with a conservation easement and the value of that easement, as determined by a qualified appraisal, is characterized as a charitable donation. A purchased easement means that the landowner burdens his property with a conservation easement, but rather than donating the value of the easement, he is paid that value in cash either from federal, state, or local funds, or a combination of them. A bargain sale means that the landowner donates a portion of the conservation easement as a charitable donation and is paid for the balance of the easement value. Often, the conservation easement is held and monitored by a land trust with whom the landowner negotiates the terms of the agreement. The landowner is in essence contracting with the land trust to perform all of the work needed to complete the transaction of placing the land into an easement. As such, all expenses related to the transaction are the responsibility of the landowner. These expenses can range from $\$ 20,000$ to $\$ 50,000$.

\subsection{The role of a land trust}

Land trusts are private, nonprofit organizations whose mission involves land and water conservation. They help negotiate individually tailored, voluntary agreements with property owners to keep land undeveloped. In the United States, land trusts are monitored and guided by a national organization called the Land Trust Alliance (LTA). The LTA serves as the national advocacy organization for the land trust community and promulgates a set of standards and practices for local land trusts to maintain. In most cases, the landowner and land trust negotiate a monetary stewardship donation that the landowner pays to the land trust to cover future monitoring costs and maintenance of records. At a minimum, annual monitoring is a necessary component of a conservation easement to ensure that the terms of the agreement are being upheld and the integrity of the conservation values remain intact.

A land trust's board of directors performs a risk analysis of each project the land trust accepts because they are taking on the potential risk of defending the conservation easement. Full due diligence is also required in performing a title examination and understanding the mineral estate. In Texas, this is very important due to the significant oil and gas development across the state. In the case of Herff Farm, there were several lawsuits in its past to quiet title to determine who actually owned the land. In addition, mineral title work was performed because the landowner was not completely sure if the mineral estate was owned outright. The land trust's directors required this step, and it was determined that the landowner in fact owned all of the minerals. Another unique element of this project dealt with the historical structures on the farm. CNC\&F wanted to protect the structures through the easement, but Texas Agricultural Land Trust did not want to take on undue risk in the maintenance of historic structures, so the buildings were not included in the agreement.

\subsection{Conservation easement valuation}

Due to market prices, regional differences, land use differences and a number of other variables, determining a conservation easement's value is best done by an official appraisal, 
and is a requirement for any of the three types of easements. In very general terms, a $30 \%$ reduction in value is a conservative starting point in the absence of a qualified appraisal. The only exception when an appraisal is optional is if a landowner is donating an easement and not declaring it as a charitable contribution for tax benefits. At the time of this writing, the range in Texas for the cost of an appraisal ran between $\$ 7,500$ and $\$ 15,000$, depending on the complexity of the transaction. For unique properties such as Herff Farm, it is important that the appraiser be familiar with valuing conservation easements, as standard property comparisons may be difficult to ascertain.

The appraiser's job is to clarify the conservation easement value, or the value of the development rights. Fig. 2 illustrates the financial breakdown of the conservation easement value. The first step is to determine the market value of the subject property with the development rights intact (represented by the whole bar). The second step is to determine the potential value of the development rights of the subject property. This is also referred to as a percentage reduction in value. Once the development rights are valued, that becomes the conservation easement value. Private landowners may charitably donate that value and receive a tax benefit, apply to a purchased easement program to be paid that value, or choose to donate a portion of that value and be paid for the balance. Herff Farm was valued at approximately $\$ 3.5$ million before the conservation easement and $\$ 1.5$ million after the conservation easement, resulting in a property valuation reduction of $\$ 2$ million, or $57 \%$.

\subsection{Qualified conservation contribution}

To incentivize land conservation in the United States, land conservation was codified in the Internal Revenue Service tax code as a charitable contribution. Therefore, landowners who donate the value of the conservation easement may be eligible for federal income tax, as well as potential estate tax, benefits. For estate value purposes, land burdened with a conservation easement will be valued at its "after conservation easement" value rather than its "before conservation easement" value. Internal Revenue Code section 170(h) reads as follows:

(4) Conservation purpose defined

(A) In general, for purposes of this subsection, the term "conservation purpose" means-

(i) the preservation of land areas for outdoor recreation by, or the education of, the general public,

(ii) the protection of a relatively natural habitat of fish, wildlife, or plants, or similar ecosystem,

(iii) the preservation of open space (including farmland and forest land) where such preservation is-

(I) for the scenic enjoyment of the general public, or

(II) pursuant to a clearly delineated Federal, State, or local governmental conservation policy, and will yield a significant public benefit, or

(iv) the preservation of an historically important land area or a certified historic structure [4].

Land conservation projects can fall into one or more of these categories and these purposes are enumerated in the conservation easement. Adherence to these purposes is a key component whether a landowner is donating the easement or being paid for it. In the donative case, a landowner could be receiving significant tax benefits in exchange for conserving land. If the landowner should ever violate the conservation easement, he or she 


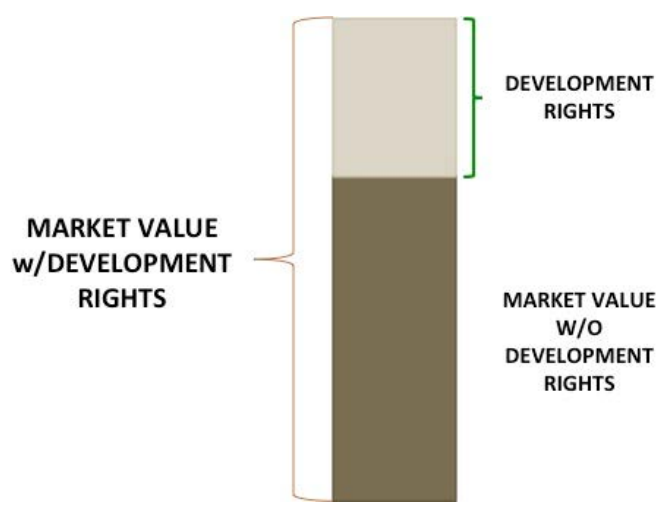

Figure 2: Conservation easement value expressed as the value of development rights.

could also be subject to punitive measure from the IRS due to the tax benefits they received. That is why part of the landowner relationship with a land trust involves annual monitoring visits whereby the land trust ensures that the land stewardship practices align with the conservation easement. Failure to comply with annual monitoring on the part of the land trust could jeopardize the landowner's tax treatment, as well as the land trust's accreditation status.

\section{HISTORIC REHABILITATION TAX CREDITS}

In the United States, both the federal and state governments recognize the value of historic preservation and have sought to incentivize private investment in rehabilitating historic structures through tax incentives. At the federal level, a program administered by the Internal Revenue Service and the National Park Service in conjunction with State Historic Preservation Offices allows for a $20 \%$ tax credit for the certified rehabilitation of certified historic buildings. In 2015, the State of Texas joined 33 other states with state historic tax credits when it launched a similar program that is worth a tax credit of $25 \%$ of Qualified Rehabilitation Expenses (QREs). Separately or combined, the programs promote revitalization of existing structures, often spurring redevelopment in inner-city neighborhoods and/or helping to maintain the unique character of a community. In addition, these projects create new jobs, increase property values and augment the income, real estate and business tax base of state and local government [5]. The Texas state tax credit has created a new market of buyers and sellers, drawing the attention of real estate developers and investors to Texas. The ability to combine state and federal historic tax credits changes the bottom line in real estate pro forms and helps leverage historic buildings as assets, which are otherwise sometimes viewed as liabilities. The availability of the state tax credit for small preservation projects may have the greatest impact on historic preservation efforts across the state as small towns begin to see new investment in downtown commercial districts and rural areas.

"Historic preservation" is often used in the pejorative as a term associated with restrictions on property rights and naysayers opposing demolition of old buildings. Historic preservation is not in and of itself often associated with economic development or financial incentives. No doubt, historic designation comes with restrictions and more regulation than most people care to deal with. As preservationists and city planners know, historic preservation is a valuable tool in creating and maintaining sustainable neighborhoods that 
are walkable, affordable and desirable places to live. Quality rehabilitation work requires skilled labor and patience to look for and find appropriate materials. Ultimately, a rehabilitation project must make economic sense. Historic tax credits legitimize the cultural and historical value of preservation in financial terms. Historic tax credits have been impacting the bottom line of such real estate investments for decades, and now Texas has a new tool to increase the number and size of rehabilitation projects.

\subsection{Federal Historic Preservation Tax Incentives}

A tax credit creates a dollar-for-dollar reduction in the tax owed to the government. The Rehabilitation Investment Tax Credit was created by Congress in 1978 with the passage of the Tax Act [6]. The tax credit program began as a $10 \%$ credit, but is now worth a $20 \%$ credit against federal income taxes. The Historic Rehabilitation Tax Credit (HRTC) is the federal government's most significant financial investment in historic preservation. It has been part of the federal tax code since 1982. During its 30 plus years, the HRTC has created more than 2.35 million jobs and leveraged over $\$ 106$ billion in private investments all by putting more than 38,700 buildings back into productive use [7]. Across the country, the federal incentive, worth $20 \%$ of qualified rehabilitation expenses, is seen as an economic development driver, not just a preservation tool [8].

\subsection{Texas Historic Preservation Tax Credit}

Texas became the thirty-fourth state to take advantage of this economic incentive by creating a state historic tax credit that works with the federal credit to incentivize large redevelopment projects. The state credit also promotes small redevelopment projects that do not meet the qualifications of the federal program. The most-used state credit programs have a few commonalities including: transferability, lack of project cap, and lack of program cap. With thirty-three state programs created before the Texas program, the authors of the legislation had the ability to research and understand what makes a successful statewide historic tax credit program. HB500 was written in such a way that the Texas program has the three most important characteristics of a strong program: transferability of the credit, no cap on the overall program, nor an individual project cap. The Texas Historic Tax Credit was crafted in such a way as to actually incentivize expensive, challenging rehabilitation projects in small towns and big cities alike. While the Federal Historic Tax Credit has done little to incentivize small rehabilitation projects because of the requirement to spend the adjusted basis of the building on the rehabilitation project and the difficulty in transferring credits, the Texas state tax credit has increased the number of small rehabilitation projects because non-profits can easily use the credit and the minimum amount spent is only $\$ 5,000$.

To be eligible, a property must be a certified historic structure and undergo certified rehabilitation. There are some differences between federal and state requirements, but both entities define rehabilitation and Qualified Rehabilitation Expenses the same. Rehabilitation "makes possible a compatible use for a property through repair, alterations, and additions while preserving those portions or features which convey its historical, cultural, or architectural values [9].” The National Park Service and Texas Historical Commission [10] interpret the Secretary of the Interior's standards on a building-by-building basis since each project is unique. Features of historical significance that remain on the exterior and interior of the property are evaluated, using the current condition as a starting point. Expenses such as structural repairs, internal systems, roofing, and fees by architects, engineers and other 
construction experts are allowable. Ineligible expenses include property acquisition, building additions, furnishings, parking lots, sidewalks, and landscaping [10].

\subsection{A special opportunity for non-profit organizations}

Because the Herff Farm is owned and operated by a non-profit organization, it is not subject to income tax and therefore did not qualify for the federal tax credit. Yet, as a nonprofit with a mission to conserve natural and cultural resources, seeking out creative revenue opportunities is essential to the organization's long-term viability. As mentioned above, Texas does not have state income tax. For-profit businesses are charged a franchise tax. Therefore, the State of Texas Historic Preservation Tax Credit offers a tax credit certificate to qualified applicants, and those who cannot use the credit themselves, such as non-profit organizations, may sell or transfer it through an independent agreement [10]. Selling the tax credit at a discount enables the non-profit organization to recoup a portion of the rehabilitation costs, while the entity purchasing the credit lowers its overall tax bill by the amount of the discount. In the case of the Herff Farm, the Cibolo Nature Center \& Farm was able to recoup nearly $20 \%$ of its overall construction investment in the main homestead's rehabilitation.

Table 1: Comparison of Federal and State Historic Tax Credit Programs [10].

\begin{tabular}{|c|c|c|}
\hline & Federal & State of Texas \\
\hline Credit applies to: & Federal Income Tax & Texas Franchise Tax \\
\hline Percent credit offered: & $20 \%$ of QREs & $25 \%$ of QREs \\
\hline Credit recipient: & Current owner(s) & $\begin{array}{l}\text { Current owner(s) }- \text { may } \\
\text { transfer credit to others }\end{array}$ \\
\hline Eligible applicants & $\begin{array}{l}\text { Individuals, companies, } \\
\text { partnerships }\end{array}$ & $\begin{array}{l}\text { Individuals, companies, } \\
\text { partnerships, nonprofits and } \\
\text { government entities }\end{array}$ \\
\hline Eligible building uses: & Income-producing only & Income-producing or nonprofit \\
\hline $\begin{array}{l}\text { Required } \\
\text { designation: }\end{array}$ & National Register & $\begin{array}{l}\text { National Register, Registered } \\
\text { Texas Historic Landmark or } \\
\text { State Antiquities Landmark }\end{array}$ \\
\hline Minimum project: & $\begin{array}{l}\$ 5,000 / \text { value of building } \\
\text { (whichever is greater) }\end{array}$ & $\$ 5,000$ \\
\hline Application structure: & 3-part Federal application & $\begin{array}{l}\text { 3-part application that mirrors } \\
\text { Federal }\end{array}$ \\
\hline Recapture period: & 5 years & No recapture period \\
\hline $\begin{array}{l}\text { Time limit for use of } \\
\text { credits: }\end{array}$ & 20 years & 5 years \\
\hline Architectural oversight: & $\begin{array}{lrr}\text { National Park } & \text { Service } \\
\text { certifies } & \text { with } & \text { THC's } \\
\text { recommendation } & \\
\end{array}$ & $\begin{array}{l}\text { THC certifies projects NPS } \\
\text { reviews first is applying for } \\
\text { Federal and State }\end{array}$ \\
\hline Financial oversight: & Credit managed by IRS & $\begin{array}{l}\text { Credit managed by Texas } \\
\text { Comptroller }\end{array}$ \\
\hline Application deadline: & $\begin{array}{l}\text { Must apply before project } \\
\text { completion }\end{array}$ & $\begin{array}{l}\text { Must apply before project } \\
\text { completion }\end{array}$ \\
\hline
\end{tabular}


Table 2: Rehabilitation expenses and tax credit for Herff Farm.

\begin{tabular}{|l|r|}
\hline Total rehabilitation expenses & $\$ 600,181$ \\
\hline Qualified rehabilitation expenses & $\$ 526,809$ \\
\hline 25\% Texas Historic Preservation Tax Credit & $\$ 131,702$ \\
\hline Sale price of tax credit & $\$ 118,530$ \\
\hline$\%$ tax credit proceeds to total expenses & $19.75 \%$ \\
\hline
\end{tabular}

The Cibolo Nature Center and Farm has plans to rehabilitate the historic barn on the property in the coming years for community meeting space and use by its existing Nature Preschool. As it was included as a building of significance in the National Register of Historic Places designation, a portion of the barn's rehabilitation expenses may be eligible for the Texas Historic Preservation Tax Credit. As design and construction costs continue to rise, utilization of this tool will be increasingly valuable.

Due to its nonprofit status, the CNC\&F was not able to take advantage of the tax incentives of a conservation easement on Herff Farm either. However, ensuring the conservation values in perpetuity was deemed an important precaution by the organization's board of directors. In so doing, future decision-makers will be prevented from converting the property's use into another purpose. Commissioning an appraisal of the property demonstrated to the members and funders what a significant financial step was taken by placing the conservation easement on the farm, even though this was not a requirement of the donated easement. With historic Herff Farm permanently preserved through a conservation easement, investors, members and visitors may rest assured that the property will remain substantially as it exists today, with the exception of a few prenegotiated mission-related improvements. This allows financial supporters of the nonprofit organization to be secure in their knowledge that their donations are going to the purpose they intend, and that it will be in existence for the long haul.

Fiscal sustainability is the ongoing challenge for a nonprofit that owns physical property requiring perpetual maintenance. A key requirement will be for the $\mathrm{CNC} \& \mathrm{~F}$ to continue to broaden its base of support through innovative and relevant programming while balancing the carrying capacity of the Herff Farm home and grounds.

\section{REFERENCES}

[1] Texas Land Trends, Online. www.txlandtrends.org/data/Compare/Areas/c_Kendall \%7Ci_Hill-Country. Accessed on: 20 Oct. 2016.

[2] Deed of Conservation Easement for Herff Farm, State of Texas, Kendall County, Doc \#00301594, 1520, p. 221.

[3] National Register of Historic Places Registration Form, Herff-Rozelle Farm, 2009.

[4] Tax Code, Regulations and Official Guidance, Internal Revenue Service, Online. www.irs.gov.

[5] Historic Preservation Tax Credits; National Park Service, U.S. Department of the Interior, Online. www.nps.gov/tps/tax-incentives/taxdocs/about-tax-incentives2012.pdf. Accessed on: 11 Feb. 2017.

[6] Tyler, N., Ligibel, T.J. \& Tyler, I.R., Historic Preservation: An Introduction to its History, Principles, and Practice, 2, p. 209. W.W. Warton \& Company, Inc.: New York, NY, 2009.

[7] Yots, J., Historic rehab industry sails into tax credit safe harbor. The Preservation Exchange, Online. www.preservationexchange.Blogspot.com/2014/01/0-false-18-pt18-pt-0-0-false-false.html. Accessed on: 1 Jan. 2014. 
[8] Prosperity through preservation: Save the historic tax credit, National Trust Community Investment Corporation: Washington, D.C., 25 Jun. 2015.

[9] Murphy, J., Leibowitz, J. \& Magolan, V., Conservation for the long haul. American Planning Association Conference 2016 Texas State Planning Conference, 4 Nov. 2016.

[10] Texas Historical Commission, Online. www.thc.texas.gov. 